\title{
THE STUDY OF DEPENDENCE OF THE RESONANCE FREQUENCIES OF DIFFERENTIAL SENSOR ON THE INTRUDER'S APPROACHING
}

\author{
Nabiyev Rasim Nasib oglu, head of Aviation Electronic, dr. of tech.sc., the department of the \\ Scientific Research Institute of Transport and Aerospace Problems, National Aviation Academy of \\ Azerbaijan, Azerbaijan, ORCID ID: https://orcid.org/0000-0002-1727-0360 \\ Garaev Gadir Isahan oglu, Electronics engineer of Aviation Electronic, candidate of tech.sc., the \\ department of the Scientific Research Institute of Transport and Aerospace Problems, National \\ Aviation Academy of Azerbaijan, Azerbaijan, ORCID ID: https://orcid.org/0000-0001-7232-669X \\ Rustamov Ruslan Rustam oglu, Senior Lecturer of the Department of Aviation Security and the \\ person working for doctor's degree, National Aviation Academy of Azerbaijan, Azerbaijan, \\ ORCID ID: https://orcid.org/0000-0001-6969-6796
}

DOI: https://doi.org/10.31435/rsglobal_conf/30042021/7526

Abstract. The article described the studies in laboratory and outdoor experiments the feasibility of use
of two auto-generators with sensitive elements, which were built on the digital logic elements, in the
security warning systems for guarding of the objects of civil aviation as capacitance differential
sensors. In experiments, the frequency variations of auto-generators are studied depending on the
distance of approaching and length of sensitive elements. It is found that when the length is less than 6
$m$, the sensitive elements are connected to the auto-generators as elements with lumped parameters,
whereas of the length is more than $6 m$ - as elements with distributed parameters. Keywords: Differential sensor, intruder's approaching, resonance frequency, aviation security, security warning system, sensitive element.

Introduction. In modern times, the provision of stable operation and protection of strategically important civil aviation facilities that ensure the international air transportation, including the improvement of the aviation security against new manifestations of terrorism, and the promotion of the reputation of any state in this area in the international arena are of great importance $[1,2]$.

The timely, sustainable and reliable response to expected threats depends on the integration level of security-warning systems of strategically important facilities. Sustainable and reliable operation enables early detection of possible threats to the security-warning system, regardless of the environmental impact [3-5]. One of the various control facilities integrated into these systems, which detect the intruder (object) at an early stage, are the capacitance sensors [6].

The approaching of an object (for example, a human) can be detected through the sensors [7]. The sensitivity distance of the sensor, its adaptation to environmental changes, as well as the design of the used auto-generators [8, 9], the size of the sensitive elements (SEs), and the installation configuration have to be comprehensively studied [10].

The purpose of the article is to determine the feasibility of use of two auto-generators, which were built on digital logic elements, with SEs as differential sensors.

For this purpose, dependence of frequency changes of two auto-generators, build on digital logic elements, which was connected SEs, and of sensitivity distance of these auto-generators as differential sensors on SEs' length were studied.

Research methods. Two auto-generators are installed on the same printing board using two digital microcircuits the type of К155ЛА3. The logic elements contained in both microcircuits are symmetrically cross-distributed in the auto-generators circuits [9]. In all experiments, the metal case of the sensors, where auto-generators circuits and frequency measuring device are located, is grounded in accordance with real operating conditions [7] and additionally placed in a hermetic plastic container to be protected from rain during the implementation of outdoors experiments (Figures 1a, 1b). The figure shows the frequencies recorded with the video camera. 


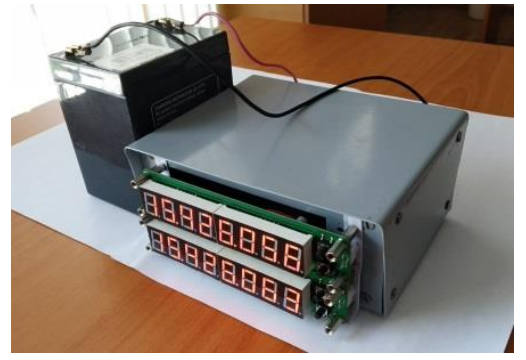

a)

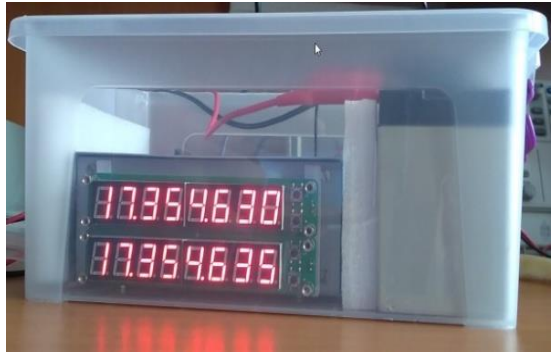

b)

Fig. 1. Differential capacitance sensor in metal case (a) and hermetic container (b).

The experiments were performed on the territory of the National Aviation Academy (NAA) and the facility where the VOR-DME (VOR - Omni-directional range; DME - distance measuring equipment) is located. In the experiments, the frequencies of the auto-generators were measured using two eight-digit frequency measuring devices of SKU00653 model. The accuracy of these frequency measuring devices was verified by "GW Instek GOS 620" oscillator, and their high accuracy (accuracy of $0.1 \mathrm{~Hz}$ at $1 \mathrm{MHz}$ frequency) was defined [11]. GoPro video camera with 250 frames per second was used to record fast frequency variations.

The experiments performed on different days in laboratories and outdoor (in the territory of NAA and VOR-DME system facilities) are described below.

1. Dependence of frequency variation on the lengths of SEs. Dependence of the frequency variations on the length of SE was studied in three days in the environments provided in Table 1.

Table 1. Weather condition in three days experiments

\begin{tabular}{|c|c|c|c|c|}
\hline Days & $\begin{array}{c}\text { Weather Temperature, } \\
\left({ }^{\circ} \mathbf{C}\right)\end{array}$ & $\begin{array}{c}\text { Atmospheric pressure, } \\
(\mathbf{m m} \text { mercury })\end{array}$ & $\begin{array}{c}\text { Humidity, } \\
(\boldsymbol{\%})\end{array}$ & Source \\
\hline I & $22-24$ & $750-758$ & $50-60$ & {$[12]$} \\
\hline II & $21-23$ & 761 & $45-50$ & {$[13]$} \\
\hline III & $26-28$ & 757 & $45-50$ & {$[14]$} \\
\hline
\end{tabular}

During the study, SEs of $2 \mathrm{~m}, 5 \mathrm{~m}, 6 \mathrm{~m}, 10 \mathrm{~m}, 20 \mathrm{~m}, 30 \mathrm{~m}, 40 \mathrm{~m}$ and $50 \mathrm{~m}$, as well as the copper wires of $4.5 \mathrm{~m}$ long are used to cover the sensor case with soil. The HEs are directly connected to each of the auto-generators separately. The experiments were performed on the territory of the navigation facility (Figures $2 \mathrm{a}, 2 \mathrm{~b}$ ).

Once enabled, the frequencies of both auto-generators account, are 17.12 MHz without SEs and grounding, $17.01 \mathrm{MHz}$ after 60 seconds, and $16.82 \mathrm{MHz}$ when their case was grounded.

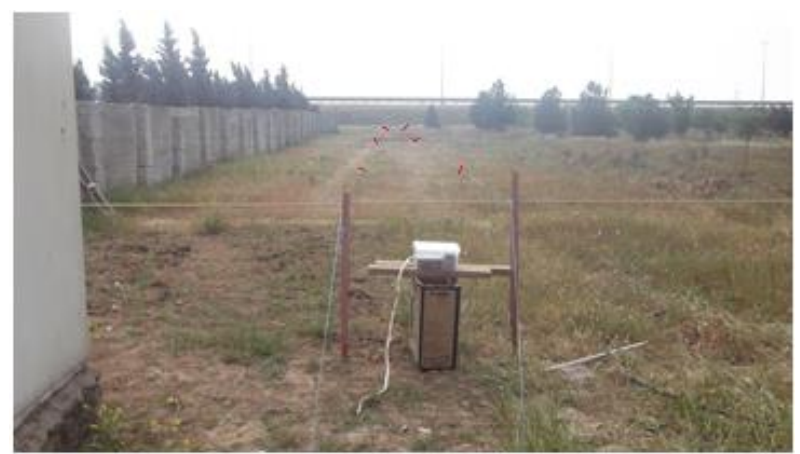

a)

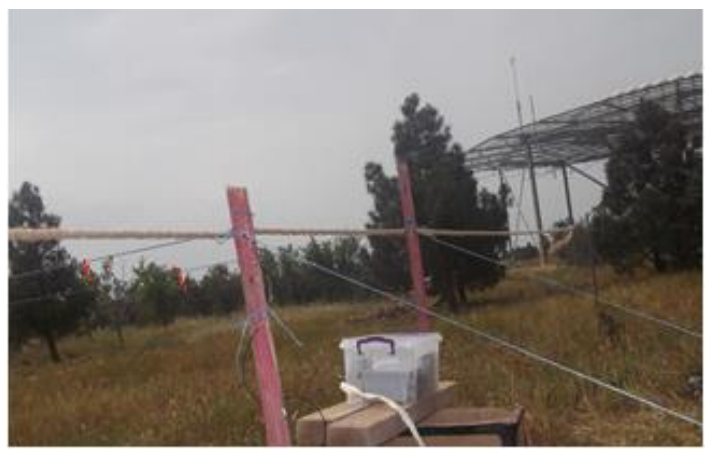

b)

Fig. 2. Experience in VOR-DME area: a) rear view, b) side view.

Graphic depictions of the average values of frequency variations recorded for three different days, depending on the lengths of the SEs were provided in Figure 3. Since the frequencies are repeated with $0.01 \mathrm{MHz}$ accuracy, the frequencies of both auto-generators are shown as one curve. 


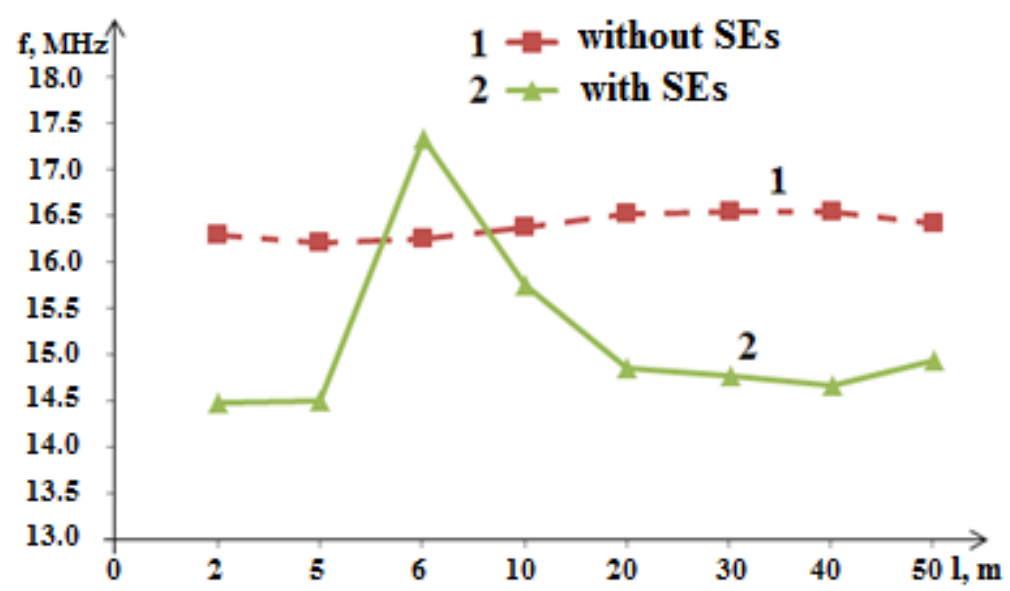

Fig. 3. Graphical representation for the average values of the frequency variations of the autogenerators in three different days depending on the lengths of the SEs

As seen from the figure, the frequencies of both auto-generators without SEs vary around 16.5 $\mathrm{MHz}$ at a range of less than $\pm 0.5 \mathrm{MHz}$ (Figure $3,1^{\text {st }}$ curve).

With the exclusion of 6 and $10 \mathrm{~m}$, the frequencies of both auto-generators vary around 14.5 MHz at all other lengths of the SEs. Here, the case of the SE of $6 \mathrm{~m}$ is specific. In this case, in all experiments performed in three different days, the frequencies of both auto-generators are often higher than those without SE, accounting for $\mathrm{f}_{\mathrm{I} \text { mid. }}=17.345066 \mathrm{MHz}$ and $\mathrm{f}_{\mathrm{I} \text { mid. }}=17.345066 \mathrm{MHz}$ (Figure 3, $2^{\text {nd }}$ curve) respectively.

2. Experiments performed with approaching. The dependence of sensitivity distance of the sensors on the length of the SEs has been studied. In this regard, the frequencies of the auto-generators were recorded when a person with weight $\mathrm{m}$ (the researcher's weight is $93 \mathrm{~kg}$ ) approached to SEs of $2 \mathrm{~m}, 5 \mathrm{~m}, 10 \mathrm{~m}$ and $50 \mathrm{~m}$.

2.1. Experiments conducted in laboratory conditions. The auto-generators are connected to two wires as the SEs, each of which is $2 \mathrm{~m}$ in length, as well as parallel to each other and to the floor. The wires are fastened to the dielectric supports, at a distance of $0.1 \mathrm{~m}$ from each other and $1 \mathrm{~m}$ from the floor.

During the study, the approaching was performed perpendicularly to the midpoint of the SE starting at a distance of $3 \mathrm{~m}$, and the frequency values were recorded for the approaching at each meter $(1=3 ; 2 ; 1 ; 0 \mathrm{~m})($ Table 2$) .1=0$ is the value when a person touches the SE.

Table 2. The frequencies values of two auto-generators when approaching to SE at $2 \mathrm{~m}$

\begin{tabular}{|c|c|c|}
\hline $\mathbf{I}(\mathbf{m})$ & I auto-generator, $\left.\mathbf{f}_{\mathbf{1}} \mathbf{( M H z}\right)$ & II auto-generator, $\left.\mathbf{f}_{\mathbf{2}} \mathbf{( M H z}\right)$ \\
\hline $\mathbf{0}$ & 13.661799 & 13.661016 \\
\hline $\mathbf{1}$ & 13.781477 & 13.778263 \\
\hline $\mathbf{2}$ & 13.811120 & 13.811674 \\
\hline $\mathbf{3}$ & 13.813097 & 13.813492 \\
\hline
\end{tabular}

The difference between the resonance frequencies $\left(\Delta \mathrm{f}_{\mathrm{ob}}\right)$ at zero (when touching) and $3 \mathrm{~m}$ distance from a person to $\mathrm{SE}$ accounts for $\Delta \mathrm{f}_{\mathrm{ob}}=0.1151298 \mathrm{MHz}$ for the $1^{\text {st }}$ generator, and $\Delta \mathrm{f}_{\mathrm{ob}}=0.1152476 \mathrm{MHz}$ for the $2^{\text {nd }}$ generator, respectively.

The lengths for SEs were selected $5 \mathrm{~m}$. During the study, the approaching is performed perpendicular towards SEs from three different points starting at a distance of $3 \mathrm{~m}$ (in the $1^{\text {st }}$ case, from the point connected to the auto-generator; in the $2^{\text {nd }}$ case, from the midpoint; in the $3^{\text {rd }}$ case, from the edge) (Table 3 ). 
Table 3. The frequencies values of two auto-generators when approaching to SE at $5 \mathrm{~m}$

\begin{tabular}{|c|c|c|c|c|c|c|}
\hline \multirow{2}{*}{$\begin{array}{c}\mathbf{I} \\
(\mathbf{m})\end{array}$} & \multicolumn{2}{|c|}{ I auto-generator, $\mathbf{f}_{\mathbf{1}}(\mathbf{M H z})$} & \multicolumn{3}{c|}{ II auto-generator, $\mathbf{f}_{\mathbf{2}}$ (MHz) } \\
\hline $\mathbf{0}$ & 11.238468 & 11.207155 & 11.209304 & 11.238467 & 11.207335 & 11.209322 \\
\hline $\mathbf{1}$ & 11.240973 & 11.238147 & 11.238210 & 11.240965 & 11.238169 & 11.238253 \\
\hline $\mathbf{2}$ & 11.241044 & 11.241434 & 11.242047 & 11.241045 & 11.241435 & 11.242048 \\
\hline $\mathbf{3}$ & 11.241095 & 11.241639 & 11.242341 & 11.241093 & 11.241640 & 11.242341 \\
\hline
\end{tabular}

The variation in frequency relative to the moment of touching to SE when the object approaching, are:

on the $\mathbf{1}^{\text {st }}$ auto-generator,
I case $\Delta \mathrm{f}_{\mathrm{ob}}=0.002627 \mathrm{MHz}$,
II case $\Delta \mathrm{f}_{\mathrm{ob}}=0.034484 \mathrm{MHz}$,
III case $\Delta \mathrm{f}_{\mathrm{ob}}=0.033037 \mathrm{MHz}$;

on the $2^{\text {nd }}$ auto-generator
I case $\Delta \mathrm{f}_{\mathrm{ob}}=0.002626 \mathrm{MHz}$,
II case $\Delta \mathrm{f}_{\mathrm{ob}}=0.034305 \mathrm{MHz}$,
III case $\Delta \mathrm{f}_{\mathrm{ob}}=0.033019 \mathrm{MHz}$.

The graphs of frequency variations are illustrated in Figure 4. Apparently, the resonance frequencies of the auto-generators when approaching to SEs vary in the same way and decrease.
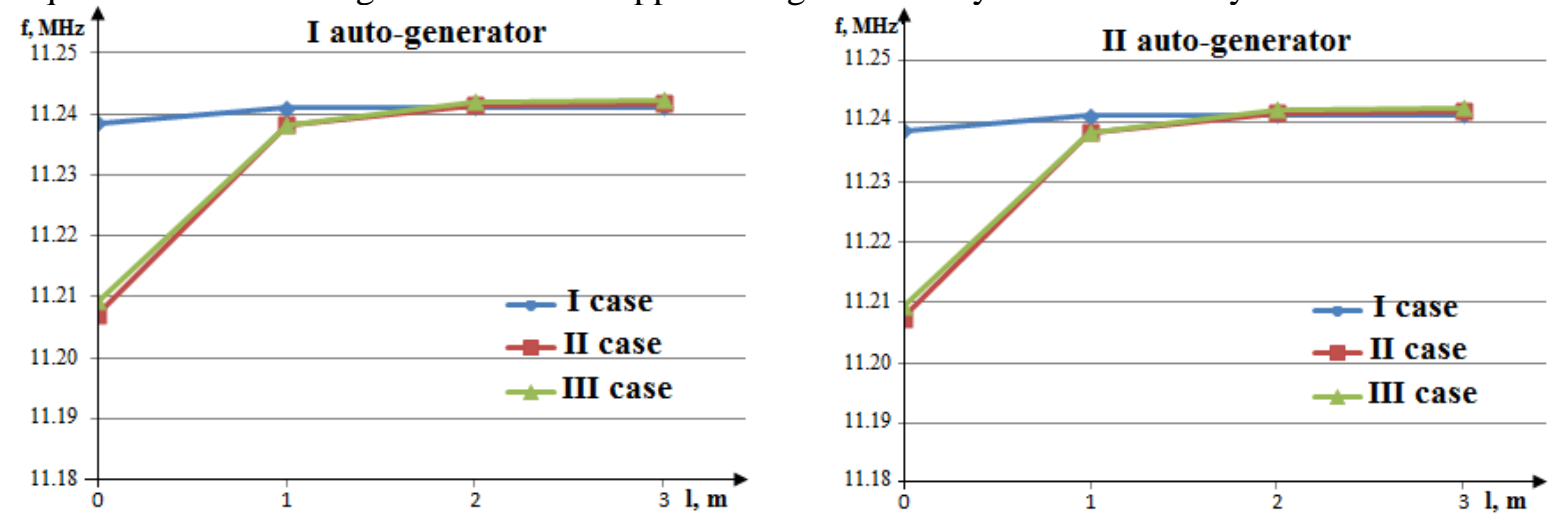

Fig. 4. Dependence of resonance frequencies on human approaching distance to SEs, which are $5 \mathrm{~m}$ lengths of each and were connected to the auto-generators

2.2. Experiments performed in an open area. Two wires, each $10 \mathrm{~m}$ length, are connected to the auto-generators as SEs via coaxial cables of $5 \mathrm{~m}$ (Figure $2 \mathrm{a}, 2 \mathrm{~b}$ ). The wires are fastened to dielectric supports at distance and height of $1 \mathrm{~m}$, in parallel to each other and to the surface of the Earth. The experiments were performed in the same sequence as stated in 2.1, and the recorded values of the frequency variations were provided in table (Table 4).

Table 4. The frequencies values of two auto-generators when approaching to SE at $10 \mathrm{~m}$

\begin{tabular}{|c|c|c|c|c|c|c|}
\hline \multirow{2}{*}{$\begin{array}{c}\mathbf{I} \\
(\mathbf{m})\end{array}$} & \multicolumn{2}{|c|}{ I auto-generator, $\mathbf{f}_{\mathbf{1}}(\mathbf{M H z})$} & \multicolumn{2}{c|}{ II auto-generator, $\mathbf{f}_{\mathbf{2}}(\mathbf{M H z})$} \\
\cline { 2 - 7 } & I case & II case & I case & II case & I case & II case \\
\hline $\mathbf{0}$ & 19.420569 & 19.461813 & 19.428018 & 19.420550 & 19.461812 & 19.428026 \\
\hline $\mathbf{1}$ & 19.443941 & 19.461900 & 19.440790 & 19.443925 & 19.461904 & 19.440768 \\
\hline $\mathbf{2}$ & 19.462565 & 19.462243 & 19.455898 & 19.462567 & 19.462248 & 19.455902 \\
\hline $\mathbf{3}$ & 19.461537 & 19.458791 & 19.454895 & 19.461540 & 19.458793 & 19.454899 \\
\hline
\end{tabular}

According to Table 4, the resonance frequencies of both auto-generators vary in all cases, increasing when approaching towards SEs at the distance from $3 \mathrm{~m}$ to $2 \mathrm{~m}$, and decreasing when approaching towards SEs at the distance of $2 \mathrm{~m}$ to touching point. On the I auto-generator, in the I case, $\Delta \mathrm{f}_{\mathrm{ob}}=0.041996 \mathrm{MHz}$, in the II case, $\Delta \mathrm{f}_{\mathrm{ob}}=0.003452 \mathrm{MHz}$, and in the III case, $\Delta \mathrm{f}_{\mathrm{ob}}=0.02788 \mathrm{MHz}$; On the II auto-generator, in the I case, $\Delta \mathrm{f}_{\mathrm{ob}}=0.042017 \mathrm{MHz}$, in the II case, $\Delta \mathrm{f}_{\mathrm{ob}}=0.003455 \mathrm{MHz}$, and in the III case, $\Delta \mathrm{f}_{\mathrm{ob}}=0.027876 \mathrm{MHz}$. 
Two wires of $50 \mathrm{~m}$ were connected directly to the auto-generator as the SEs (Figure $2 \mathrm{a}, \mathrm{b}$ ). The wires are fastened as in the abovementioned cases.

Experiments were performed in the sequence shown in Experiments 2.1 and 2.2, and the recorded values of the frequency variations were presented at Table 5.

Table 5. The frequencies values of two auto-generators when approaching to SE at $50 \mathrm{~m}$

\begin{tabular}{|c|c|c|c|c|c|c|}
\hline \multirow{2}{*}{$\begin{array}{c}\mathbf{L} \\
(\mathbf{m})\end{array}$} & \multicolumn{3}{|c|}{ I auto-generator, $\mathbf{f}_{\mathbf{1}}(\mathbf{M H z})$} & \multicolumn{2}{c|}{ II auto-generator, $\mathbf{f}_{\mathbf{2}}$ (MHz) } \\
\hline $\mathbf{0}$ & 14.993379 & 14.937367 & 14.937740 & 14.993377 & 14.937355 & 14.937738 \\
\hline $\mathbf{1}$ & 14.990632 & 14.974322 & 14.973409 & 14.990640 & 14.974321 & 14.973408 \\
\hline $\mathbf{2}$ & 14.987608 & 14.986177 & 14.983077 & 14.987605 & 14.986175 & 14.983071 \\
\hline $\mathbf{3}$ & 14.986868 & 14.986205 & 14.983303 & 14.986866 & 14.986203 & 14.983301 \\
\hline
\end{tabular}

The variation in frequency relative to the moment of touching to SE when the object approaching, are:

on the $1^{\text {st }}$ auto-generator,
I case $\Delta \mathrm{f}_{\mathrm{ob}}=0.006511 \mathrm{MHz}$,
II case $\Delta \mathrm{f}_{\mathrm{ob}}=0.048838 \mathrm{MHz}$
III case $\Delta \mathrm{f}_{\mathrm{ob}}=0.045563 \mathrm{MHz}$;

on the $2^{\text {nd }}$ auto-generator
I case $\Delta \mathrm{f}_{\mathrm{ob}}=0.006511 \mathrm{MHz}$,
II case $\Delta \mathrm{f}_{\mathrm{ob}}=0.048848 \mathrm{MHz}$,
III case $\Delta \mathrm{f}_{\mathrm{ob}}=0.045563 \mathrm{MHz}$,

The graphs representing the frequency variations were presented in Figure 5. Apparently, when approaching the SEs, the resonance frequencies of the auto-generators change in the same way, increasing in the I case and decreasing in the II and III cases, respectively.
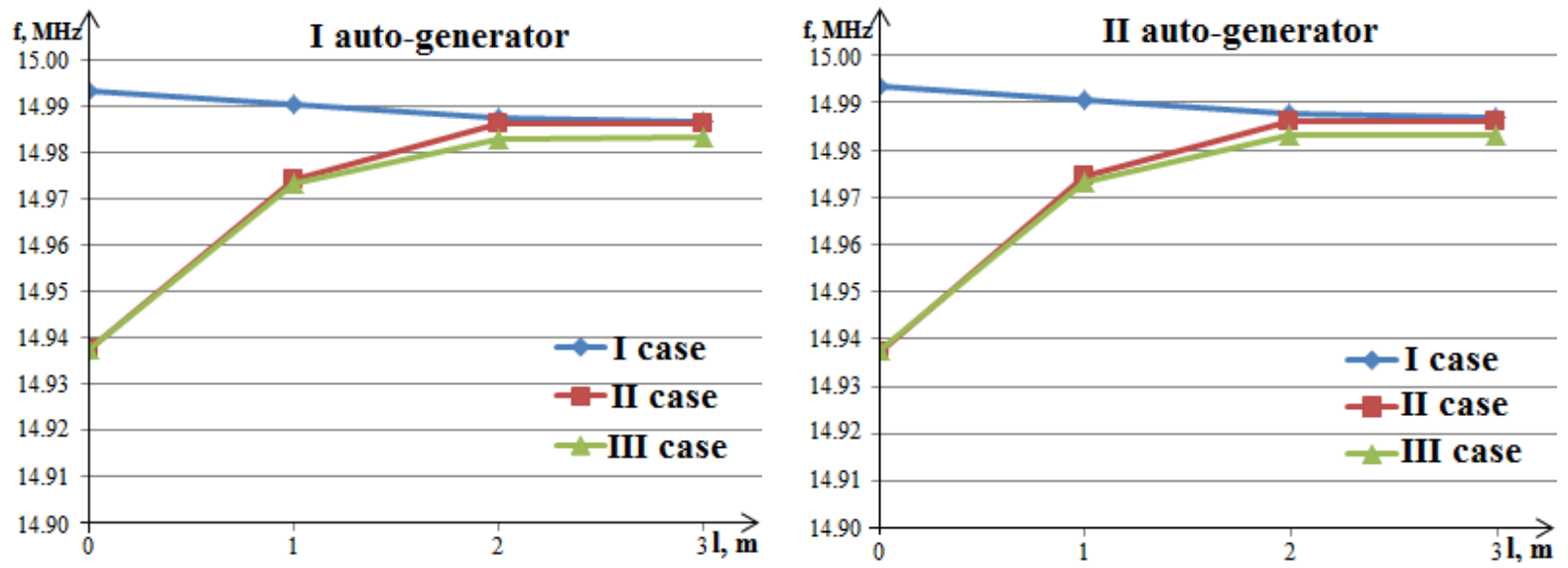

Fig. 5. Dependence of resonance frequencies on the distance of a human approaching the SE of $50 \mathrm{~m}$ connected to the auto-generators

Taking into account the time-dependent drift of the resonance frequency of the auto-generators $\left(\Delta \mathrm{f}_{\mathrm{t} . \mathrm{I}}= \pm 0.004001 \mathrm{MHz}\right.$ and $\left.\Delta \mathrm{f}_{\mathrm{t} . \mathrm{II}}= \pm 0.003998 \mathrm{MHz}\right)$, the sensitive elements of which are $50 \mathrm{~m}$ length of each, the discreteness value of the measured parameters $\mathrm{n}_{\text {d.v }}$ for the I auto-generator is $\mathrm{n}_{\text {d.v }} \approx 2$ in the I case, $\mathrm{n}_{\text {d.v }} \approx 12$ in the II case, and $\mathrm{n}_{\text {d.v }} \approx 11$ in the III case, and for the auto-generator is $\mathrm{n}_{\mathrm{d} . \mathrm{v}} \approx 2$ in the I case, $\mathrm{n}_{\mathrm{d} . \mathrm{v}} \approx 12$ in the II case, and $\mathrm{n}_{\mathrm{d} . \mathrm{v}} \approx 11$ in the III case, which enables determining the weight of the approaching object at a distance of more than $3 \mathrm{~m}$.

Research results. When a person of $93 \mathrm{~kg}$ weight perpendicularly approached the SEs at a distance of $3 \mathrm{~m}$, the frequency of the auto-generators changed. These variations accounted for as follows:

- if the length of the SEs was $2 \mathrm{~m}-\Delta \mathrm{f}_{\mathrm{ob}}=0.1151298 \mathrm{MHz}$ for the I auto-generator; $\Delta \mathrm{f}_{\mathrm{ob}}=0.1152476 \mathrm{MHz}$ for the II auto-generator;

- if the length of the SEs was $5 \mathrm{~m}$, then for the I auto-generator $\Delta \mathrm{f}_{\mathrm{ob}}=0.002627 \mathrm{MHz}$ in the I case, $\Delta \mathrm{f}_{\mathrm{ob}}=0.034484 \mathrm{MHz}$ in the II case, $\Delta \mathrm{f}_{\mathrm{ob}}=0.033037 \mathrm{MHz}$ in the III case; for the II auto-generator $\Delta \mathrm{f}_{\mathrm{ob}}=0.002626 \mathrm{MHz}$ in the I case, $\Delta \mathrm{f}_{\mathrm{ob}}=0.034305 \mathrm{MHz}$ in the II case, $\Delta \mathrm{f}_{\mathrm{ob}}=0.033019 \mathrm{MHz}$ in the III case; 
- if coaxial cables of $5 \mathrm{~m}$ length were connected to the SE of $10 \mathrm{~m}$ - for the I auto-generator $\Delta \mathrm{f}_{\mathrm{ob}}=0.041996 \mathrm{MHz}$ in the I case, $\Delta \mathrm{f}_{\mathrm{ob}}=0.003452 \mathrm{MHz}$ in the II case, $\Delta \mathrm{f}_{\mathrm{ob}}=0.02788 \mathrm{MHz}$ in the III case; and for the II auto-generator $\Delta \mathrm{f}_{\mathrm{ob}}=0.042017 \mathrm{MHz}$ in the I case, $\Delta \mathrm{f}_{\mathrm{ob}}=0.003455 \mathrm{MHz}$ in the II case, and $\Delta \mathrm{f}_{\mathrm{ob}}=0.027876 \mathrm{MHz}$ in the III case.

Taking into account the time-dependent drift $\left(\Delta \mathrm{f}_{\mathrm{t} . \mathrm{I}}= \pm 0.004001 \mathrm{MHs}\right.$ and $\left.\Delta \mathrm{f}_{\mathrm{t} . \mathrm{II}}= \pm 0.003998 \mathrm{MHs}\right)$ of the value of the resonance frequency of auto-generators, the sensitive element of which was $50 \mathrm{~m}$ length, the discreteness value of the measured parameters $\mathrm{n}_{\mathrm{d} . \mathrm{v}}$ for both auto-generators was $\mathrm{n}_{\text {d.v }}=2$ in the I case, $\mathrm{n}_{\text {d.v }}=12$ in the II case, and $\mathrm{n}_{\text {d.v }}=11$ in the III case which allowed determining the weight of the approaching object at a distance of more than $3 \mathrm{~m}$.

When reviewing the resonance frequency variations depending on the length of the SEs, we saw that the lowest values of the auto-generators' frequencies were recorded when the length of the SEs was $2 \mathrm{~m}\left(\mathrm{f}_{\mathrm{I} \text { mid. }}=14.479189 \mathrm{MHz}\right.$ and $\left.\mathrm{f}_{\mathrm{II} \text { mid. }}=14.479186 \mathrm{MHz}\right)$. It should be noted that the values of the resonant frequencies on both auto-generators were less than those without SEs, however greater than those with the SEs of $6 \mathrm{~m}\left(\mathrm{f}_{\mathrm{I} \text { mid. }}=17.345066 \mathrm{MHz}\right.$ and $\left.\mathrm{f}_{\mathrm{II} \text { mid. }}=17.345066 \mathrm{MHz}\right)$.

Conclusions. The SEs of $6 \mathrm{~m}$ were connected to the auto-generator as the sensors with an lumped parameter, whereas the SEs of greater than $6 \mathrm{~m}$ were connected to the auto-generator as the sensors with distributed parameters (long line).

Thus, based on the mentioned features and the results of approaching experiments, we can conclude that the auto-generator circuits with sensitive element built on logic elements in differential sensors used in the security and warning systems of the territories of facilities are applicable. In this case, regardless of the length of the SEs, the differential sensors are automatically adapted to the environmental changes.

\section{REFERENCES}

1. Priority outcomes // ICAO. Global aviation security plan, November 2017, p. 11;

2. Preventive security measures // Annex 17 to the Convention on International Civil Aviation. Security. Safeguarding International Civil Aviation Against Acts of Unlawful Interference, march 2020, № 11. Chapter 4, page 25-29;

3. Пашаев А.М., Набиев Р.Н., Нагиев Н.Т., Велиева Г.Д., Рустамов Р.Р. Особенности проектирования автоматизированного дистанционного охранного комплекса // Вопросы безопасности. 2018, № 1. C.32-51. (in Russian with an abstract in English);

4. Paşayev A.M., Nəbiyev R.N., Ramazanov K.Ș., Rüstəmov R.R. Avtomatlaşdırılmış mühafizə-xəbərdarlıq sisteminin etibarlılı̆̆ının qiymətləndiril-məsi // Milli Aviasiya Akademiyasının Elmi Osərləri. 2018, -№2. səh. 11-27 (in Azerbaijan with an abstract in English);

5. Торокин, А. А. Инженерно-техническая защита информации: учеб. пособие / А.А. Торокин. - М.: Гелиос АРВ, 2005, 960 с. (in Russian);

6. Rüstəmov R.R. İnteqrasiya olunmuş mühafizə-xəbərdarlıq sisteminin tətbiqi perspektivləri // Azərbaycan Milli Aerokosmik Agentliyinin Xəbərləri. 2020, - №3 (23). səh. $47-53$ (in Azerbaijan with an abstract in English);

7. Nəbiyev R.N., Qarayev Q.I.., Ramazanov K.Ş., Rüstəmov R.R. LC-generatorunun tezliyinin onun həssas elementinə yaxınlaşma məsafəsindən ası1ılığı // Milli Aviasiya Akademiyasının Elmi Đsərləri. 2018, №1. səh. 28-41 (in Azerbaijan with an abstract in English);

8. Набиев Р.Н., Гараев Г.И., Рустамов Р.Р. Сравнительный анализ электрических схем ёмкостных датчиков // Известия ЮФУ. Технические науки. 2017, № 3 (188). С. $51-64$ (in Russian with an abstract in English);

9. Набиев Р.Н., Гараев Г.И., Рустамов Р.Р. Исследование схем автогенераторов для емкостных датчиков / Международная Объединенная Академия Наук, Наука России: цели и задачи, Сборник научных трудов по материалам XV международной научной конференции, Екатеринбург, 10 июня 2019 г. Часть 1. стр. 51-53 (in Russian with an abstract in English);

10. Якунин А.Г., Галков А.В. Емкостная адаптивная охранная система. // Патент РФ № 229767 от 27.12.2006 г. от 20.04.2007 г. (булл-нл 1) (in Russian);

11. Дедюхин Александр, Осциллографы компании Инструмент доброй воли // Компоненты и технологии, 2000, №9, с. 98-103 (in Russian with an abstract in English);

12. Retrieved from https://report.az/ekologiya/sabaha-yagis-yagacaq-simsek-caxacaq/ [accessed 03. 05. 2019];

13. Retrieved from https://news.milli.az/society/752377.html [accessed 05. 05. 2019];

14. Retrieved from http://eco.gov.az/az/xeberler/9-mayda-gozlenilen-hava-seraiti-9396 [accessed 08. 05. 2019]. 